\title{
Study on the Value and Cultivation Path of Carrying Out Happiness Education in Police College
}

\author{
Fan Zhang \\ School of Police Skills and Tactics, Nanjing Forest Police College, Nanjing 210023, China. \\ Zhangfan@nfpc.edu.cn
}

\begin{abstract}
This study explores the issue of happiness education in police colleges by means of literature and interviews. Results show that police's happiness directly determines their role in maintaining social stability, and improving police's happiness is an important part of improving the whole social well-being. As police colleges shoulder the arduous task of delivering the future people's police to the society, it is very important to carry out happiness education in police colleges. The author points out that there are some problems in carrying out happiness education in police colleges, such as lack of talent training program and fragmentation of education. It is necessary to improve happiness education by incorporating relevant contents into the training program, systematically implementing happiness education, guiding campus culture, and carrying out social practice activities.
\end{abstract}

Keywords: Happiness education; Police college; Social practice; Campus culture.

\section{Introduction}

The outlook on happiness is a part of the outlook on life. It is the fundamental view and viewpoint of people on happiness and reflects people's value pursuit. In peacetime, the public security organ is an important department to safeguard national security and social stability. Whether the police have a correct outlook on happiness directly affects the faithful performance of the police's duty mission and the full play of its function. To a large extent, the police's happiness concept reflects the value orientation of the whole society and affects the pace of social development. Therefore, improving police's happiness is an important part of improving the whole social well-being. As the cradle of training future policemen, police colleges bear the responsibility of shaping the correct concept of happiness of police groups. Guiding police students to establish a correct outlook on happiness is an important part of training excellent reserve police personnel in police colleges.

\section{Necessity of Developing Happiness Education in Police Colleges}

\subsection{Happiness Education Helps to Guide Students to Establish a Correct Outlook on Life.}

As a generation growing up in the drastic social change, the pressure and competition faced by modern college students are increasing day by day, and the ideological impact is also increasing. They are experiencing a turning point in their outlook on life and values from inquiry to stereotyping. Many college students often fall into the misunderstanding and blind area of different ideas: some students are covered by material interests, put the pursuit of money and material enjoyment at the top of their life goals, and think that having money and quality of material life is happiness. Some students think that opportunity is the key to decide whether a person is happy or not. In order to achieve their so-called happiness, they have no choice but to resort to any means. Moral sense and sense of responsibility are seriously lacking. They deny that happiness depends on down-to-earth work and creation, resulting in distorted outlook on happiness such as money worship and hedonism. If we can't educate these students appropriately, they may go farther and farther on the road of distorted happiness outlook, and scientific and correct happiness outlook will promote them to establish a positive outlook on life [1]. The guidance of the concept of happiness in police colleges is to enrich and enrich the students' spiritual world, help them correctly understand and cope with the current era and multi-culture, establish and practice a scientific, correct and reasonable concept of happiness, which has a far-reaching impact on the future career of police academics. 


\subsection{Happiness Education is Helpful for Students' Learning and Future Police Profession.}

As an important organ to maintain national security and social stability, police's happiness is closely related to maintaining social stability and harmony. Major social responsibility, high-risk working environment, low social support, general treatment and other issues lead to the low happiness index of the whole police group.

Nowadays, most college students are only children, and they receive good cultural education from an early age. On the whole, college students' outlook on happiness shows a healthy and positive trend. College students are not deeply involved in the world, love life, full of passion, and are active in learning and communication. Research shows that more than half of college students think they are happier [2]. But when they leave school and join in the work, there is a big gap between the comfortable campus life and the tense working atmosphere, and students have a lower sense of happiness in their work. Work is cumbersome and complicated, suffers some grievances, and even is not understood and supported by the masses. These are the situations that the police may encounter in their daily work. Police shoulder the responsibility of social stability and harmony, serving the people, the difficulties in work are always unavoidable. Frustration education is an important part of happiness education in police colleges. To improve students' ability to resist frustration and pressure, we should face all kinds of challenges in our work. At the same time, we should enhance students' sense of professional identity and belonging, and raise the police from the level of professional livelihood to the level of career pursuit. In this way, the police college students can face the negative emotions correctly, serve the people, care for the vulnerable groups, overcome the difficulties of work, recognize their own social value, and enhance their sense of happiness.

\section{The Present Situation of the Education of Happiness in Police Colleges}

Only when students in police colleges have a scientific and correct outlook on happiness can they really love the profession of police, enjoy and create the happiness belonging to police and convey it to the people they serve. But a scientific and correct view of happiness is not innate. It requires the conscious education and guidance of schools, as well as the modest learning and profound experience of students. In the specific process of education, due to the influence of various factors, there are some problems in the education of happiness outlook in police colleges, which restrict the cultivation of students' correct happiness outlook.

\subsection{Lack of Happiness Education Content in Personnel Training Program.}

The happiness education in police colleges cannot mention specific problems such as educational content, methods and methods, because this educational content is basically in a blank state in the personnel training program. According to the survey, the happiness concept education in the curriculum design of police colleges is only slightly related to the "criminal psychology" part of the "criminal motivation" of this course. Teachers usually pass by in class, leaving little impression on students' minds.

\section{2 "Fragmentation" of Happiness Education in Police Colleges.}

Class meetings and team meetings are regular ideological and political education platforms in police colleges. Team leaders and secretaries also carry out some happiness education in class meetings and team meetings. But it only pays attention to instilling relevant theoretical knowledge, the content is large and empty, overemphasizes the rational color of happiness education, divorces from the era color of College Students' life and the legitimate human basis, and makes students' disgust difficult to accept. Moreover, this kind of happiness education is sporadic and scattered, lacking of system and planning.

\subsection{Education Method of Happiness Emphasizes Explicit While Neglects Implicit.}

Generally speaking, the individual perception of happiness of police college students mainly comes from explicit and implicit education. The education of explicit happiness concept refers to the 
education of Students' Happiness Concept specially arranged by school, family and social education subjects, that is, the education of happiness concept for which the educational subjects intentionally do it [3]. The implicit happiness education refers to the unintentionally arranged happiness education that can influence the real attitude of various social subjects (such as teachers, parents, relatives and friends, etc.) to happiness and the words and deeds about happiness. For a long time, police colleges have failed to integrate explicit happiness education with implicit happiness education [4]. They have always attached importance to the teaching of classroom book culture, but have not paid enough attention to the influence of campus culture and other social subjects on the formation of students' happiness view. Sometimes they are completely separated and self-contradictory.

\section{Ways to Develop the Education of Happiness in Police Colleges}

At present, the education of happiness outlook in police colleges cannot achieve effective educational effect. Therefore, we must explore ways to carry out the education of happiness outlook, improve the education of happiness outlook in an all-round way, and form a multi-level education system of happiness outlook.

\subsection{Happiness Education is Systematically Included in the Talent Training Program.}

Happiness education is a complex system engineering, involving many aspects and levels. It should be carried out continuously and run through the whole university stage of learning. Firstly, the content of happiness education should be included in public basic courses. The courses of "Ideological and Moral Cultivation and Legal Basis" and "General Psychology" offered by freshmen of police colleges need to set up special contents of happiness education, elaborate happiness concept at the level of moral education and basic psychological education, and help students master the basic theoretical knowledge of happiness concept. Secondly, the content of happiness education should be infiltrated into professional courses [5]. For example, "People's Police Law", "Public Security Administrative Law Enforcement" and other professional courses infiltrate Happiness Concept education, so that students will imperceptibly integrate the correct happiness concept and future police profession, highlighting the police characteristics and professional connotations of happiness concept education. Finally, regular lectures on happiness education are offered. Schools should arrange special lectures for teachers of different majors, interpret the content of happiness concept from different disciplinary perspectives, and help students understand the content of happiness concept from multiple perspectives and levels.

\subsection{Strengthen the Educational Atmosphere of Happiness Outlook in Campus Culture.}

High-quality campus cultural activities can enable students to attach importance to the construction of their personal spiritual world and enhance their moral ideals and spiritual realm. Rich and colorful campus cultural activities can be fun to teach, ease students' tension, create a positive and upward police cultural atmosphere, so that students can be edified and educated in such an atmosphere, thus having an optimistic attitude, good psychological quality, forming correct values, and cultivating healthy personality strength.

\subsection{To Deepen the Understanding of the Concept of Happiness Through Social Practice.}

Happiness is conditioned by the individual's feelings. Therefore, the education of the concept of happiness should not only be carried out in the classroom, but also be integrated into various social activities, so that students can experience the joy of dedication and the resulting sense of happiness in social practice, and deepen their understanding of the concept of happiness. One is to create conditions for education and teaching. Schools can organize students to study and practice. Make full use of the self-education and self-management organizations of College Students' associations and associations, give full play to the positive role of summer social practice, volunteer activities, community activities and so on, organize students to carry out happiness education practice activities in the society and the masses, and actively guide students to learn in practice [6]. Secondly, we should 
open our minds to create opportunities, occasions and conditions for students to express themselves. In the classroom, case-based, situational, interactive and seminar-based teaching modes are adopted to enable students to participate actively. Carry out a big discussion or speech debate on the concept of happiness. Set up a happiness view forum, through specific examples in life, to provide students with the opportunity to express and discuss their outlook on life and values. Third, improve students' ability to perceive happiness in daily life. We should guide students to find and feel the existence of happiness from the dribs and drabs of daily life. We should start from the reasonable and abundant needs of learning knowledge, exchanging family feelings, pursuing love and obtaining friendship to perceive the harmonious state of happiness, and improve students' ability to discover and feel happiness.

\section{Summary}

Happiness perception and creation is an important ability. Strengthening the education of students' happiness outlook in police colleges plays an important role in training future police who are selfless, impartial, dedicated, in-depth with the masses and willing to serve. Therefore, we should further actively explore a systematic, all-round and multi-level operation system of happiness education in police colleges, so that happiness education can be effectively carried out in police colleges is an important mission of every police educator.

\section{Acknowledgements}

This research was financially supported in part by the 13th Five-Year plan project of Jiangsu Education Science under Grant C-c/2018/01/11, in part by Jiangsu Qing Lan Project under Grant 2017 (Excellent Teaching Team of NFPC), in part by Overseas Research and Study Project of Excellent Young and Middle-aged Teachers in Colleges of Jiangsu Province of 2018.

\section{References}

[1]. WANG Yanjie, ZHENG Qinqin. Exploration on the Path of Implementing "Struggle for Happiness" Education in Colleges and Universities. Journal of Yan'an University (Social Science Edition). Vol. 41 (2019) No. 1, p. 125-128.

[2]. BAI Pengfei, WANG Xinliang. Construction of the Education System of College Students' Multiple Happiness View. The Theory and Practice of Innovation and Entreptrneurship. Vol. 2 (2019) No. 1, p. 155-156.

[3]. SHANG Zhixia. The Education of University Students' View of "Struggle for Happiness" in the New period. Journal of Hubei Normal University. Vol. 39 (2019) No. 3, p. 108-112.

[4]. ZHANG Tinghui, LI Chuanying. A Survey of Happiness and Happiness Education for College Students. Journal of Liuzhou Teachers College. Vol. 32 (2017) No. 5, p. 87-90.

[5]. LI Jiamei. On the Happiness Value Education of College Students. Journal of Jishou University. Vol. 34 (2013) No. 2, p. 124-128.

[6]. Feng Dashuang. Experience and Enlightenment to the Contemporary College Students' Happiness Ideas Education in American. Future and Development. Vol. 42 (2018) No. 3, p. 35 39. 